\title{
Phytochemical Properties and Diverse Beneficial Roles of Eucalyptus globulus Labill.: A Review
}

\author{
Awad Y. Shala 1,*(D) and Mayank Anand Gururani ${ }^{2, *(D)}$ \\ 1 Medicinal and Aromatic Plants Research Department, Horticulture Research Institute, Agricultural Research \\ Center, Giza 12619, Egypt \\ 2 Biology Department, College of Science, United Arab Emirates University, \\ Al Ain 15551, United Arab Emirates \\ * Correspondence: to: awad.shala@yahoo.com (A.Y.S.); gururani@uaeu.ac.ae (M.A.G.)
}

Citation: Shala, A.Y.; Gururani, M.A. Phytochemical Properties and Diverse Beneficial Roles of Eucalyptus globulus Labill.: A Review. Horticulturae 2021, 7, 450. https:/ / doi.org/10.3390/horticulturae7110450

Academic Editor: Luigi De Bellis

Received: 5 October 2021

Accepted: 25 October 2021

Published: 2 November 2021

Publisher's Note: MDPI stays neutral with regard to jurisdictional claims in published maps and institutional affiliations.

Copyright: (c) 2021 by the authors. Licensee MDPI, Basel, Switzerland. This article is an open access article distributed under the terms and conditions of the Creative Commons Attribution (CC BY) license (https:/ / creativecommons.org/licenses/by/ $4.0 /)$.
Abstract: Eucalyptus globulus Labill. is one of the most widely utilized medicinal plants throughout the world due to its wide spectrum of interesting biological activities that are mainly attributed to the diversity of phytochemical constituents in the plant parts. The emerging crisis of pathogen resistance for conventional antibiotics is considered a global concern for the diminishing effectiveness of antibiotics; hence, there is an urgent need to explore new antimicrobial ingredients from botanical sources, among which the most promising sources are medicinal plants. Moreover, the growing limitation toward synthetic antioxidants motivated the scientific community all over the world to identify plant-acquired antioxidants and antimicrobials. This is a huge global challenge, because of the increasing public health awareness and reliance on natural compounds, as these compounds are safer alternatives. Moreover, the undesirable impacts of synthetic pharmaceuticals can be avoided. Furthermore, plant extracts and their oil could be used as eco-friendly plant-based products for insects, weeds, and plant pathogen control, which will diminish the dependence on synthetic chemicals. Thus, this review is to highlight the richness of the E. globulus plant, with precious bioactive constituents, antioxidants, antimicrobials, and phytoremediation, and herbicidal activities, which will pave the way to the development of new pharmaceuticals and agrochemicals, as well as food preservatives. They may also provide potential commercial applications to counteract the limitations of synthetic antioxidants.

Keywords: antimicrobial activity; antioxidant activity; E. globulus; essential oil; herbicidal activity; 1,8-cineole; phytoremediation

\section{Introduction}

E. globulus belongs to the family of Myrtaceae; an evergreen broadleaf tree, with a straight trunk, indigenous to Australia, the genus Eucalyptus comprises of more than 700 species [1]. It is known as "the blue gum" or Tasmanian blue gum. Nowadays, E. globulus is extensively cultivated worldwide [2-16] because of its easy adaptability to environmental conditions, ease of cultivation, fast growth rate, and increase in the woody biomass. Furthermore, it can be planted in contaminated areas [17]. Obviously, Eucalyptus can adapt to biotic and abiotic stresses by selectively releasing defense compounds mainly of mono- and sesquiterpenes, as well as some hydrocarbons and quinones [18]. E. globulus has attracted the attention of researchers as well as environmentalists worldwide, due to it commonly being used in the pulp industry as a fast-growing source, and for the essential oil extracted from its leaves. Commercially, it is widely used for different purposes.

The essential oil of Eucalyptus spp. is among the 18 most frequently traded essential oils throughout the world. On account of this, there is an increasing amount of attention paid to their advantages as raw materials, which can be used in food, pharmaceuticals, and cosmetics, both in scientific and industrial research [1,19]. Among them E. globulus Labill. is the main source of the Eucalyptus leaf oil used globally [3]. Its leaves are alternate, 
with yellowish petioles, precisely lanceolate, $10-30 \mathrm{~cm}$ long, $2.5-5 \mathrm{~cm}$ wide, shiny dark green on both surfaces, and are a rich source of essential oil [7,10,20-22]. The oil is typically extracted by hydrodistillation, as the greatest amount of extracted chemical compounds can be obtained by utilizing this method $[4,15,21]$. The essential oil yield ranges from $1-3 \%[1,3,9,19,20,23]$. The chemical composition of the Eucalyptus leaf essential oil is a complex mixture of substances, commonly containing 20 to 54 components with varying concentrations $[4,8,13,15,24]$. The oil comprised particularly of oxygenated monoterpenes $(80.65-87.32 \%)$ as well as monoterpene hydrocarbons $(18.33-12.45 \%)[9,25]$.

The extracted leaf essential oil is more or less pale yellow and has a pleasant odor, having a camphor-like smell $[5,20,26]$. The physical properties of this oil include a refractive index from $1.4657 \pm 0.0070$ to $1.4693 \pm 0.00057$, a specific gravity from 0.913 to $0.919 \mathrm{~g} / \mathrm{cm}^{3}[5,20]$, an optical rotation of +1.5956 , and a $\mathrm{pH}\left(22^{\circ} \mathrm{C}\right)$ of 4.9 [5]. The chemical properties of the extracted leaf essential oil, which include acid value, saponification value, hydroxyl value, and iodine value, are $0.5945,19.576,31.61$, and 41.52 , respectively [5]. All of the previous physicochemical properties are considered significant for oil quality determination, especially for marketing strategies.

The major component of the essential oil of Eucalyptus leaves is monoterpene oxide 1,8-cineole (Figure 1), also known as Eucalyptol [3,9,13,20,21]. Eucalyptol is commonly utilized in flavoring, fragrance, and cosmetics. This is attributable to its pleasant spicy aroma and taste. It is also used in mouthwash applications and cough suppressants [22]. The commercial value of the essential oil depends chiefly on the existence of 1,8 -cineole $[9,26]$. Consequently, the absence of 1,8-cineole and existence of $\alpha$-phellandrene in the Nigeriangrown E. globulus, which has a high cytotoxic effect, make the oil suitable for insecticidal formulations and inappropriate for medicinal purposes [27].

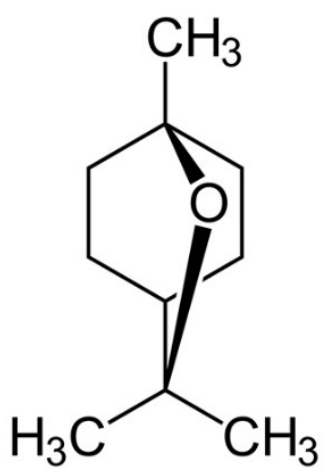

1, 8-cineol (Eucalyptol)

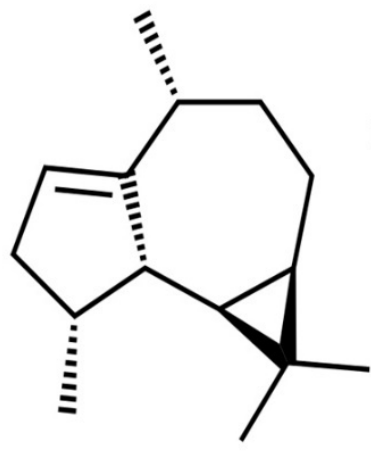

Aromadendrene

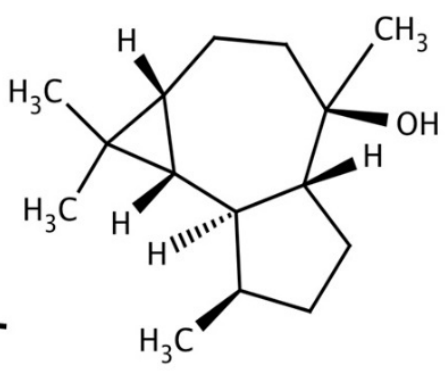

Globulol

Figure 1. Chemical structures of the main components of Eucalyptus leaf and fruit essential oils.

Eucalyptus leaf essential oil has drawn the attention of numerous researchers, as it represents a wide range of biological potentials, such as antibacterial efficacy toward both Gram-positive and Gram-negative bacteria $[28,29]$ and considerable antibacterial potency against periodontal diseases $[20,30]$. Therefore, it can be incorporated into dental care products, as it is an anti-inflammatory agent $[10,31]$; has antifungal $[16,28,32,33]$ and antidiabetic potential [34,35]; insecticidal [36-39], acaricidal, and repellent activities; is a biodegradable pesticide [40]; has bio-nematicide efficacy [7], phytopathogen control [8,23], and anthelmintic activity [41]; and it is a natural agent for food preservation [25]. Furthermore, this leaf essential oil has been previously applied in "folk medicine, in the treatment of respiratory problems, including, cold, cough, runny nose, sore throat, asthma, nasal congestion, bronchitis, and sinusitis" [42].

In a study conducted in Germany, the authors identified the main compound in the essential oil of hydro-distilled fruits to be; aromadendrene (Figure 1), which exerted antibacterial activity [3,43]. Nevertheless, Bey-Ould Si Said et al. [44], revealed the predominance of globulol $(23.6 \%)$, which is the major component in the fruit oils extracted from 
plants growing in the north-east of Algeria (Figure 1). The essential oil of fruits possesses antibacterial activity $[43,44]$; hence, fruit oil is a potential candidate for application in the pharmaceutical and food industries.

Leaves and root extracts possess antioxidant, anti-inflammatory, and antitumor activities [35,45-47], which correlate with the elevated amount of plant phytoconstituents. Additionally, leaf extracts possess fungicidal potency [48], allelopathic potential [49-51], anti-hyperglycemic potential [52], a potential anticancer activity [53], antibacterial activity $[30,54,55]$, and neuroprotective activity [56]. In addition, leaf extracts are presently utilized in cosmetic formulations and food additives [35]. The E. globulus stump that is defined as "the basal part of the tree", including the near-the-ground stem portion, and the woody roots that remain after "stem felling", possesses antioxidant and antimicrobial activities [57].

The aim of the current review is to present recent information on the phytochemical, antioxidant, and antimicrobial aspects of the E. globulus plant parts, besides the factors influencing the essential oil composition of the plants, and also its eco-friendly applications. This may help gather fruitful information for the potential use of the plant, as a precious source of diverse ingredients, in multiple applications.

\section{Bioactive Components}

Miscellaneous investigations revealed the occurrence of considerable amounts of versatile bioactive components in the different plant parts, which are presented in Table 1. These phytochemicals are responsible for the therapeutic impacts of the plant $[2,9,43,44,47]$. In most of the studies, 1,8-cineole is the dominant component in the essential oils of leaves, with various percentages (Table 1 ), except for a few findings $[26,27,58,59]$. Furthermore, phytochemical analysis of the leaf extracts proved the presence of tannins, saponins, terpenoids, glycosides, alkaloids, phenolic compounds, steroids, cardiac glycosides, terpenes, reducing sugars, carbohydrates, resins, acidic compounds, and flavonoids $[19,30,52,60]$. In addition, the high phenolic content in the Eucalyptus plant parts (Table 1) that correlated with positive health influences against oxidative stress has also been formerly documented $[2,46,56,57,61]$. Additionally, triterpene compounds that possess significant pharmaceutical applications have been previously identified in Eucalyptus leaves, bark, and fruits [62-64].

Table 1. Phytochemical compounds reported in the different parts of E. globulus Labill.

\begin{tabular}{|c|c|c|}
\hline Plant Parts & Major Constituents & References \\
\hline Leaves & $\begin{array}{c}\text { 1,8-cineole (31.42\%) and trans-3-carven-2-ol (10.10\%), 2-Octen-1-ol, 3,7-dimethyl (9.37), and } \\
\text { Cis-p-Menth-2,8-dienol (6.33) }\end{array}$ & [36] \\
\hline Leaves & $\begin{array}{c}\text { 1,8-cineole }(86.51 \%), \alpha \text {-pinene } \\
(4.74 \%), \gamma \text {-terpinene }(2.57 \%) \text { and } \alpha \text {-phellandrene }(1.40 \%)\end{array}$ & [3] \\
\hline Leaves & 1,8-cineole (95.61\%) and alpha-pinene $(1.5 \%)$ & [65] \\
\hline Aerial parts & 1,8-cineole $(79.85 \%)$, Limonene $(6.72 \%), p$-cymene $(5.14 \%)$, and $\gamma$-terpinene $(3.93 \%)$ & [25] \\
\hline Leaves & 1,8-cineole $(85.8 \%), \alpha$-pinene $(7.2 \%)$, and $\beta$-myrcene $(1.5 \%)$ & [9] \\
\hline Leaves & $\gamma$-terpinene $(94.48 \%)$ and 1,8 -cineole $(3.20 \%)$ & [58] \\
\hline Leaves & 1,8-cineole (33.6\%), $\alpha$-pinene $(14.2 \%)$, and d-limonene $(10.1 \%)$ & [38] \\
\hline Leaves & $\begin{array}{c}\text { Terpinen-4-ol (23.46\%), } \gamma \text {-terpinene (17.01\%), pathulenol (8.94\%), } \rho \text {-ymene }(8.10 \%) \text { and } \\
\rho \text {-cymen-7-ol }(6.39 \%) \text {, globulol }(2.52 \%) \text {, and } \alpha \text {-phellandrene }(2.20 \%)\end{array}$ & [27] \\
\hline Leaves & $\begin{array}{l}\text { 1,8-cineole }(22.35 \%) \text {, limonene }(7.01 \%) \text {, solanol }(6.05 \%), \beta \text {-pinene }(5.20 \%) \text {, trans-verbenol } \\
(4.02 \%) \text {, and terpinen- } 4 \text {-ol }(3.10 \%)\end{array}$ & [8] \\
\hline Leaves & 1,8 cineole (51.08\%), $\alpha$-pinene (24.60\%), L-pinocarveol (9.98\%), and globulol (2.81) & [5] \\
\hline Leaves & 1,8-Cineole (71.05\%) and $\alpha$-pinene $(8.30 \%)$ & [1] \\
\hline Leaves & Phenolics (quercetin and luteolin) & [2] \\
\hline Leaves & $\begin{array}{c}\text { 1,8-cineole }(76.65 \%), \alpha \text {-pinene }(5.65 \%), \alpha \text {-terpineol acetate }(4.85 \%) \text {, and alloaromadendrene } \\
(3.98 \%)\end{array}$ & [11] \\
\hline
\end{tabular}


Table 1. Cont.

\begin{tabular}{|c|c|c|}
\hline Plant Parts & Major Constituents & References \\
\hline Leaves & $\begin{array}{c}\text { 1,8-cineole }(62.38 \%), \alpha \text {-pinene (23.79\%), } \alpha \text {-terpinyl acetate }(5.41 \%) \text {, globulol }(1.68 \%) \text {, and } \\
\beta \text {-pinene }(1.1 \%)\end{array}$ & [15] \\
\hline Leaves & 1,8-cineole (55.29\%), spathulenol (7.44\%), and $\alpha$-terpineol (5.46\%) & [20] \\
\hline Leaves & 1,8-cineole ( $36.68 \%), \beta$-pinene $(9.25 \%)$, aromedendrene $(6.33 \%)$, and globulol $(5.11 \%)$ & [6] \\
\hline Leaves & Chlorogenic acid, rutin, and quercetin 3-glucuronide and ellagic acid derivatives & [45] \\
\hline Leaves & $\begin{array}{c}\text { 1,8-cineole }(54.79 \%), \beta \text {-pinene }(18.54 \%), \alpha \text {-pinene }(11.46 \%), \beta \text {-eudesmol }(4.68 \%), \\
\alpha \text {-phellandrene }(2.06 \%) \text {, para cymene }(1.60 \%) \text {, and gamma-eudesmol }(1.20 \%)\end{array}$ & [4] \\
\hline Leaves & $\begin{array}{l}\text { p-Cymene (18.18\%), methyl eugenol (8.83\%), 4-Terpinenol (8.45\%), s-methyl } \\
\text { 3-methylbutanethioate (7.26\%), g-terpinene (5.12\%), and 1,8-cineole (3.16\%). }\end{array}$ & [59] \\
\hline leaves and small branches & 1,8 -cineole $(63.81 \%), \alpha$-pinene $(16.06 \%)$, aromadendrene $(3.68 \%)$, and o-cymene $(2.35 \%)$ & [13] \\
\hline Leaves & 1,8-cineole $(63.00 \%), \alpha$-pinene $(16.10 \%)$, and camphor $(3.42 \%)$ & [14] \\
\hline Leaves & 1,8-cineole $(48.2 \%), \alpha$-pinene $(16.1 \%), \gamma$-terpinene $(8.9 \%)$ and $p$-cymene $(8.8 \%)$ & [35] \\
\hline Leaves & 1,8-cineole $(75.8 \%), p$-cymene $(7.5 \%), \alpha$-pinene $(7.4 \%)$, and limonene $(6.4 \%)$ & [12] \\
\hline Leaves & 1,8-cineole $(69.32 \%)$, camphene $(9.41 \%), \alpha$-pinene $(7.48 \%)$, and $\alpha$-terpineol $(5.08 \%)$ & [23] \\
\hline Leaves & 1,8-cineole (46.76\%), D-limonene (9.61\%), and o-cymene $(6.49 \%)$ & [37] \\
\hline Leaves & $\begin{array}{l}\text { Phenolic compounds (quercetin, luteolin, kaempferol, iso-rhamnetin, phloretin, } \\
\text { chlorogenic acid) }\end{array}$ & [56] \\
\hline Leaves & $\begin{array}{l}\text { 1,8-cineole, phenolic acids (Gallic acid, ellagic acid, vanillic acid, } p \text {-hydroxybenzoic acid, } \\
\text { p-coumaric acid, and quercetin), phenolics (catechin, rutin, and luteolin) }\end{array}$ & [46] \\
\hline Leaves & $\begin{array}{c}\text { 1,8-cineole (70.94\%), 3-cyclohexene-1-ol (3.13\%), beta. fenchyl (5.38\%), } \\
\text { 1,2-benzenedicarboxylic acid (6.08\%), dodecane }(1.50 \%)\end{array}$ & [66] \\
\hline Leaves & Eucalyptol (59.63\%), p-cymene (15.55\%), and DL-limonene (14.90\%) & [16] \\
\hline Leaves & Eucalyptol (55.43\%), $\alpha$-pinene (25.55\%), and D-limonene (5.687\%) & [24] \\
\hline Leaves & $\begin{array}{c}\text { 1,8-cineol (56.83\%), L-pinocarveol ( } 10.42 \%), \alpha \text {-pinene }(9.47 \%) \text {, globulol }(7.68 \%) \text {, and } \\
\text { carvacrol }(1.59 \%)\end{array}$ & [33] \\
\hline Leaves & $p$-cymene $(20.24 \%)$, spathulenol $(14.10 \%)$, and eucalyptol $(11.30 \%)$ & [26] \\
\hline Leaves & $\begin{array}{c}\text { 1,8-cineole (23.3\%), citronellal (18.1\%), geranial (17.6\%), isopulegol (10.4\%), myrcene (13.0\%), } \\
\text { cuminaldehyde ( } 9.1 \%) \text {, and 2-pinene }(8.5 \%)\end{array}$ & [7] \\
\hline Leaves & 1,8-cineole ( $80.2 \%), p$-cymene $(6.6 \%)$, and limonene $(5 \%)$ & [10] \\
\hline Leaves & $\begin{array}{c}\text { D-limonene (23.5\%), m-cymene (24.8\%), o-cymene (9.9 and 5.4\%), 6-camphenol (7.2 and } \\
10.7 \%) \text {, terpinen-4-ol (5.2 and } 4.5 \%) \text {, and globulol (4.0 and } 12.9 \%)\end{array}$ & [34] \\
\hline Leaves & $\begin{array}{c}\text { Eucalyptol (51.62\%), } \alpha \text {-pinene }(23.62 \%), p \text {-cymene }(10 \%), \beta \text {-myrcene }(8.74 \%) \text {, terpinen- } 4 \text {-ol } \\
(2.74 \%) \text {, and } \gamma \text {-terpinene }(2.59 \%)\end{array}$ & [22] \\
\hline Leaves & 1,8-cineol (67.4 and 67.6\%) and $\alpha$-pinene (12.8 and $13.1 \%)$ & [21] \\
\hline Fruits & Aromadendrene $(31.17 \%), 1,8$-cineole $(14.55 \%)$, globulol $(10.69 \%)$, and ledene $(7.13 \%)$ & [43] \\
\hline Fruits & Globulol (23.6\%), aromadendrene (19.7\%), 1,8-cineole (19.8\%), and $\alpha$-pinene $(3.8 \%)$ & [44] \\
\hline Bark & Polyphenol and tannin & [61] \\
\hline Deciduous bark & Fatty acids, aliphatic alcohols, sterols, and triterpenoids & [63] \\
\hline Bark & $\begin{array}{l}\text { Polygalloyl glucoses (gallotannins), catechin, epicatechin, ellagic acid, } \\
\text { quercetin-3-o-rhamnoside, and isorhamnetin (phenolic compounds) }\end{array}$ & [67] \\
\hline Stump & Phenolic compounds and flavonoids & [57] \\
\hline
\end{tabular}

The anthelmintic activity of the essential oil from extracted leaves has been previously reported by Taur et al. [41]. This has been ascribed to the occurrence of valuable phytoconstituents in the oil, such as borneol, linalool, cineol, geranyl acetate, anethol, and saffrol. Additionally, phytochemical and fingerprint analyses of the essential oil from leaves displayed a higher content of flavonoids, as compared to phenols, whereas the Fourier Transform Infrared Spectrophotometer proved the existence of polyphenolic compounds, such as rutin, tannic acid, vanillic acid, and ascorbic acid, which is vastly utilized in the food industry. Furthermore, the gas chromatography analysis characterized the 
major constituents of the essential oil as 1,8 cineole (29\%), $\alpha$-pinene $(16.9 \%)$, and $\beta$-pinene $(16 \%)$ [31].

Pyrolysis gas chromatography-mass spectrometry analysis of the Eucalyptus leaves' aqueous ethanol extract identified the presence of 21 compounds and the key characterized compounds were $\beta$-eudesmol (12.84\%), $\gamma$-eudesmol (3.36\%), globulol (2.87\%), and alloaromadendrene $(3.80 \%)$; in contrast, the presence of $\alpha$-selinene and $\alpha$-gurgujene was observed in low concentrations [54]. Furthermore, the detection of guaiacol, syringol, o-cymene, catechol, and phenol could be associated with the presence of small fragments of lignin and lignin-derived monomeric products in the leaf extracts [54]. The major triterpenic acids identified in the E. globulus leaf extracts were betulinic, betulonic, oleanolic, ursolic, 3-acetyloleanolic, and 3-acetylursolic acids, which were considered to be valuable pharmaceutical compounds [62]. Gas chromatography-mass spectrometry analysis (GC-MS) of the methanolic extract identified the existence of nine compounds, 9,10-secocholesta-5,7,10(19)triene 1, 3-diol,25 [(trimethylsily) oxy] (,3ß,5Z,7E)-, 1-Heptatriacotanol, Morphinan-4,5 epoxy3,6diol, 6 [7nitrobenzofurazan-4-yl] amino, 10-Heptadecen-8-ynoic acid, methyl ester, [E]-, Ethyl Iso-allocholate, 2-Myristynoyl pantetheine, Cholesta-8,24-dien-3-ol,4-methyl-, $[3 \beta, 4 \alpha]-$, Cyclopropanedodecanoic acid, 2-octyl-, methyl ester, 9,12,15-Octadecatrienoic acid, and 2-phenyl-1,3-dioxan-5-yl ester [52]. Interestingly, hydrosol, obtained as a byproduct of leaf hydrodistillation, exhibited an effective insecticidal activity toward the mealybug, which nominated it as a potential biodegradable insecticidal compound, instead of a synthetic pesticide [68].

Regarding the chemical composition of the bark, Domingues et al. [64] reported the exploitation practicality of using the large quantities of bark generated by pulp industries as a by-product, instead of burning it for energy production, as it was rich in valuable triterpenoid compounds (betulonic, betulinic, 3-acetylbetulinic, ursolic, 3-acetylursolic, oleanolic, and 3-acetyloleanolic acids) in addition to $\beta$-amirine, $\beta$-sitosterol, palmitic acid, and aliphatic alcohols. Additionally, triterpenoid acids were chiefly concentrated in the surface layers of the trunk and the bark branches. The triterpenoid content was $1.2 \mathrm{~g} / \mathrm{kg}$ in fruits and $121.1 \mathrm{~g} / \mathrm{kg}$ in the surface layers of the bark branch residues.

Although the bark is an industrial waste product, its aqueous extract contains a natural source of antioxidant that is attributed to an abundant amount of gallotannins and some other phenolic components [67]. Similarly, the E. globulus bark has a plethora of polyphenolic compounds that exhibit anti-proliferative activity against carcinoma cells [69]. Moreover, De Melo et al. [63] stated that the deciduous bark of E. globulus contains ursolic and 3-acetylursolic acids, as the most abundant components, representing 52\% of triterpenic acids, while hexacosan-1-ol and octacosan-1-ol from aliphatic alcohols represent approximately $7 \%$ of the total extract, even as the sterols fraction represents $4.24 \%$ of the total extract and $\beta$-sitosterol represents the most of this group (Sterols) (4.05\% vs. 4.24\%).

In recent times, Lourenço et al. [70], for the first time, identified using GC-MS, eight polyhydroxy triterpenoid acids from the milled wood of mature E. globulus mature trees (40 years), the dichloromethane extract, which included "hederagenin, (4 $\alpha)$-23hydroxybetulinic acid, maslinic acid, corosolic acid, arjunolic acid, asiatic acid, caulophyllogenin, and madecassic acid, with 2,3, and 4 hydroxyl substituents", which represented $10.4 \%$ of the wood extract. These characterized compounds are known to have interesting pharmaceutical and medical applications.

\section{Factors Influencing the Essential Oil Composition of Plants}

Several studies concentrated basically on the diversity of the essential oil composition extracted from the plant leaves, which is considered the main commercial source of 1,8-cineole, as depicted in Table 1 . The fluctuation in essential oil components linked the phenological stage, environmental conditions, seasonal variations, occurrence of chemotypes, and extraction methods to geographical locations.

One of the major ingredients of the Eucalyptus leaf oil is 1,8-cineole (Eucalyptol). It is a cyclic ether with an empirical formula $\mathrm{C}_{10} \mathrm{H}_{18} \mathrm{O}$. Eucalyptol determines the commercial 
value of Eucalyptus essential oil for various industries [71]. Recent studies have demonstrated the tremendous potential of Eucalyptol and its antimicrobial properties (reviewed in [71]). It's percent and antibacterial activity depends on the specific species $[1,19]$. The predominance of Eucalyptol is overwhelming, as seen in the previous studies (Table 1). It has been formerly mentioned that oil from cultivated plants, from diverse regions of the world, denote the following various percentages: $86.51 \%$ in Germany [3], 85.8\% in Montenegro [9], 80.2\% in Turkey [10], 76.65\% in Iran [11], 75.8\% in Brazil [12], 71.05\% in Brazil [1], 69.32\% in Brazil [23], 63.81\% in Spain [13], 63.00\% in Ethiopia [14], 62.38\% in Ethiopia [15], 59.63\% in Serbia [16], 56.83\% in Algeria [33], 55.43\% in Ethiopia [24], 55.29\% in Algeria [20], 54.79\% in India [4], 51.62\% in Tanzania [22], 51.08\% in Algeria [5], 48.2\% in Tunisia [35], 46.76\% in Egypt [37], 36.68\% in Portugal [6], 23.3\% in Nigeria [7], and $22.35 \%$ in Morocco [8]. It is observed from the above cited studies that the patterns of leaf essential oil compositions differ notably in the plants cultivated in different locations, which consequently reflect on their biological activities.

On the other hand, some previous findings also characterize the various main components from plants growing in other regions, where the major component of leaf essential oil from plants grown in Algeria is identified by GC as $\gamma$-terpinene (94.48\%) and 1,8-cineole $(3.20 \%)$ [58]. Additionally, Benabdesslem et al. [26], reported that $p$-cymene $(20.24 \%)$ is the major constituent in the Algerian-grown E. globulus plants (southwest Algeria) and the authors concluded that Eucalyptus leaves originating from the same region, as well as their essential oils, can be utilized for the influenza virus, as inhalants and as a substitute for imported materials. Both the aforementioned studies were in contrast with the results obtained by Harkat-Madouri et al. [20], for the plants grown in north east Algeria, where the authors identified 1,8-cineole (55.29\%), spathulenol (7.44\%), and $\alpha$-terpineol $(5.46 \%)$ as the predominant components. The oil from the plants grown in Nigeria had terpinen-4-ol $(23.46 \%)$ as the most abundant component, but 1,8-cineole was not detected in the leaf essential oil [27]. Additionally, $p$-cymene was a predominant component in Tunisian-grown Eucalyptus and accounted for $18.18 \%$, while 1,8-cineole represented 3.16\% [59]. In contrast, Pino et al. [21] found that the chemical composition of the leaf essential oil was not significantly influenced by the growth region in Ecuador.

The phenological stage led to marked influences on the essential oil yield and composition. Salem et al. [72] found, on Tunisian-grown Eucalyptus, that the plants harvested at the late fructification stage produced the highest oil yield $(0.32 \% w / w)$ as compared to the essential oil yield of plants harvested at the vegetative and full flowering stages ( 0.11 and $0.14 \% w / w$, respectively), which was ascribed to the development of secretory structures of essential oil, that are often associated with plant ontogeny. Furthermore, plant growth development and essential oil accumulation were greatly influenced by environmental conditions. Additionally, the essential oil ingredients were also altered by the growth stage; thus, at the vegetative and full flowering stages, the major components were 1,8-cineole and $p$-cymene (13.23 and $32.19 \%$, respectively); although, in the fructification stage, the main compound was 1,8 -cineole $(37.82 \%)$.

Abdossi et al. [11] stated that the E. globulus essential oil composition was greatly influenced by environmental circumstances. According to Luís et al. [13], the variation in the main components of essential oil could be ascribed to the "genetic variation, plant organ, and different environmental factors".

With regard to seasonal variations, Usman et al. [34], found that the essential oil of E. globulus grown in north-central Nigeria had D-limonene and m-cymene chemotypes as the predominant compounds (23.5 and $24.8 \%$, respectively) detected in the leaf oil procured in the dry and rainy seasons, respectively. For efficient oil extraction from E. globulus leaves, hydrodistillation was used to produce a higher amount of oil yield, such as 1.1 and $1.21 \%$ of essential oil $(w / w$, based on the fresh weight of the mature leaves) $[4,15]$ rather than the oil obtained $(0.2 \% w / w)$ from steam distillation [5]. Although steam distillation was more favorable than traditional hydrodistillation, the aromatic oil obtained from steam distillation was appropriate for food processing as a plant-derived flavoring agent. 


\section{Antioxidant Activity of E. globulus Labill.}

The increasing awareness of synthetic antioxidants motivated a number of scholars, on a global scale, to identify alternative antioxidants of plant origin, to avoid the unfavorable effects of synthetic antioxidants $[13,34,45]$. In this regard, the antioxidant potential of different Eucalyptus plant parts (leaves, fruits, roots, and stump wood) as well as their essential oils were formerly reported as being able to be utilized to diminish oxidative stress-associated diseases, and also as food preservatives [13,31,47,57]

The leaf essential oil of Nigerian-grown E. globulus exhibited a low antioxidant capacity via its potential to scavenge DPPH radicals, with elevated $\mathrm{IC}_{50}$ values $(136.87 \mu \mathrm{L} / \mathrm{mL})$ as compared to the standard antioxidant ascorbic acid. This may be attributed to the absence of some components such as 1,8-cineole in the leaf oil as well as the potential antagonistic impact between other components in Eucalyptus oil [27]. Conversely, Luis et al. [13] reported that the essential oil of E. globulus exerted a remarkable antioxidant efficacy through its ability to scavenge DPPH radicals with an $\mathrm{IC}_{50}$ value $(2.90 \pm 0.35 \mathrm{v} / \mathrm{v})$, with respect to the $\mathrm{IC}_{50}$ value $(4.56 \pm 0.70 \mathrm{v} / \mathrm{v})$ for Eucalyptus radiata. This may be related to the existence of 1,8-cineole as the main constituent only in E. globulus essential oil, as well as the synergistic effect between other oil components. Moreover, the essential oil of E. globulus showed great activity to inhibit the lipid peroxidation with an $\mathrm{IC}_{50}$ value $(2.72 \pm 0.01 \mathrm{v} / \mathrm{v})$ inferior to the activity of the synthetic antioxidant $\mathrm{BHT}$, with an $\mathrm{IC}_{50}$ value of $3.58 \pm 0.02 \mathrm{w} / \mathrm{v}$, in the $\beta$-carotene bleaching test. This was considered a promising result that supported the E. globulus essential oil as a potential natural substitute, to overcome the adverse side effects of synthetic antioxidants, especially for food preservation.

Salem et al. [72] stated that the elevated antioxidant activity was detected at the full flowering and fructification stage; thus, a positive relationship existed between the essential oil content and its antioxidant potential. Furthermore, the essential oil of the aerial parts showed a potent DPPH scavenging capacity as well as moderate reducing power efficacy as compared with butylated hydroxyanisole (BHA) and ascorbic acid, respectively [11,34]. Additionally, the chelating ability of the ferrous ions of the essential oil extracted at the vegetative and full flowering stages was more prominent than that of the oil extracted at the fructification stage, which was attributed to the metal chelating impacts of 1,8-cineole, $\alpha$-terpineol, and methyleugenol. Interestingly, Usman et al. [34] studied the effect of the seasonal variation on the antioxidant activity of Eucalyptus essential oil and demonstrated the richness of the leaf essential oil harvested in the rainy season with oxygenated monoand sesquiterpenoids, which was reflected in its higher scavenging activity for the DPPH radical as well as significant ferric-reducing power, as compared to the leaf essential oil gathered in the dry season. Of late, Sharma et al. [68] stated that Eucalyptus essential oil evidenced a powerful antioxidant potential that was clearly observed via $\mathrm{IC}_{50}$ values of 70.12, 48.26, 17.94, and 15.45, for DPPH, Nitric oxide, Hydroxyl radical, and ABTS radical scavenging activities, respectively, as compared to $9.62,57.19,119.38$, and 127.16 , being the $\mathrm{IC}_{50}$ values for ascorbic acid, while the $\mathrm{IC}_{50}$ value of 18.37 was for the iron-reducing power, with respect to the $\mathrm{IC}_{50}$ value of ascorbic acid (59.33). The marked reducing power was an important factor for pharmacological drugs that were responsible for the alleviation of free radicals and oxidative stress-associated diseases. The authors attributed the elevated antioxidant activity of essential oil to its richness with flavonoids and phenolic compounds.

The highest phenolic content was provided by methanol and methanol:water extracts of dried Eucalyptus leaves, as compared to other utilized solvents. Additionally, the greatest antioxidant activity was achieved from the dry leaf methanol:water extract and its antioxidant efficacy strongly correlated with the phenolic content [45]. The greatest DPPH radical scavenging potential was achieved from the leaf methanol extract, with an $\mathrm{IC}_{50}$ value of $23 \mu \mathrm{g} / \mathrm{mL}$, followed by the leaf ethyl acetate extract and hexane extract, with $\mathrm{IC}_{50}$ values of 29 and $65 \mu \mathrm{g} / \mathrm{mL}$, respectively. With respect to BHT ( $\left.\mathrm{IC}_{50}=17 \mu \mathrm{g} / \mathrm{mL}\right)$ and vitamin $\mathrm{E}\left(\mathrm{IC}_{50}=26 \mu \mathrm{g} / \mathrm{mL}\right)$, the authors correlated the strongest activity of the methanol extract to its high content of phenolic compounds [35]. Similar findings were also achieved by Nile and Keum [46], wherein the leaves of the methanol extract displayed considerable 
antioxidant potency through the scavenging capacity and ferric reducing power of the DPPH radicals, as well as the $\mathrm{OH}$ radical scavenging potential, which was linked to the raised total phenolic and total flavonoid content, as compared to the chloroform and hexane extracts. Contrary to this, Bencheikh et al. (2021), revealed that the aqueous extract of the E. globulus leaves exerted the DPPH radical scavenging activity with an $\mathrm{IC}_{50}$ value of $18.9 \pm 1.5(\mu \mathrm{g} / \mathrm{mL})$ lower than BHT $(5.7 \pm 1.2 \mu \mathrm{g} / \mathrm{mL})$.

The fruit extract displayed a high reducing power capacity with an $\mathrm{IC}_{50}$ value of $39.52 \mu \mathrm{g} / \mathrm{mL}$, as compared to $\alpha$-tocopherol $(117.76 \mu \mathrm{g} / \mathrm{mL})$. Moreover, the extract represented a moderate lipid peroxidation inhibition activity. Furthermore, the authors depicted the antioxidant activity due to the abundance of phenolic compounds, especially hydrolyzable tannins, in the fruit extract [73]. The results obtained by Bey-Ould Si Said et al. [44] suggested that the essential oil extracted from the fruits of Nigerian-grown E. globulus showed lower antioxidant activities, through the higher $\mathrm{IC}_{50}$ values of the $\mathrm{DPPH}$ radical, reducing the power and lipid peroxidation activities $(27.0 \pm 0.2,32.8 \pm 1.8$, and $4.9 \pm 0.2 \mathrm{mg} \mathrm{mL}^{-1}$, respectively) with respect to the $\mathrm{IC}_{50}$ values of the tested BHA standard ( $0.05 \pm 0.0,0.03 \pm 0.0$, and $0.5 \pm 0.2 \mathrm{mg} \mathrm{mL}^{-1}$, respectively). However, the three antioxidant activities were more effective when compared with the results of the antioxidant activities of the essential oil from the leaves, observed by Harkat-Madouri et al. [20], in the same growth region where the essential oil of the hydro-distilled leaves showed a DPPH radical scavenging capacity ranging from 11.72 to $60.63 \%$ inhibition percentage, with an $\mathrm{IC}_{50}=33.33 \pm 0.55 \mathrm{mg} / \mathrm{mL}$, with respect to the standard BHA $\left(\mathrm{IC}_{50}=0.033 \pm 0.002 \mathrm{mg} / \mathrm{mL}\right)$, while the reducing power efficacy, with an $\mathrm{IC}_{50}$ value of $115.39 \pm 1.45 \mathrm{mg} / \mathrm{mL}$, was lower than the activity of the standard BHA $\left(\mathrm{IC}_{50}=0.048 \pm 0.015 \mathrm{mg} / \mathrm{mL}\right)$. Additionally, the oil exerted a high lipid peroxidation inhibition activity that had an $\mathrm{IC}_{50}$ value of $6.75 \pm 0.39 \mathrm{mg} / \mathrm{mL}$, as compared to an $\mathrm{IC}_{50}$ value of $0.455 \pm 0.19 \mathrm{mg} / \mathrm{mL}$ of the standard BHA. The abundance of ineffective compounds in the tested oil may be responsible for its low efficacy.

By using the DPPH and $\beta$-carotene bleaching test methods, the polar extracts (ethanol, methanol, and $75 \%$ aqueous ethanol) of the E. globulus stumps showed a significant antioxidant capacity, with a lower $\mathrm{IC}_{50}$ value than the non-polar extract (n-hexane). This was because the phenolic structures were easily extracted by the polar extracts, which explained the economic importance of the stumps as the oldest part of the tree. Furthermore, the ability of stump extracts to inhibit lipid peroxidation indicated the possibility of using these extracts as food preservatives, particularly with a high fat content [57]. Moreover, Ita (2020) found that the ethanol root extract of E. globulus, which considered limited outcomes, showed a potent antioxidant activity through the DPPH radical scavenging potential, promising a reducing power that correlated with the relationship between the antioxidant activity and root content of phenolics and flavonoids, which suggested that the roots were a promising source of natural antioxidants for diminishing the reactive oxygen species in biological systems. Additionally, the crude bark extracts as well as fruit extracts had an antioxidant activity that could be used as an alternative for pure compounds, such as plant-derived antioxidants [61,73], to overcome the deleterious effects of synthetic antioxidants.

\section{Antimicrobial Activity}

\subsection{Antibacterial Activity}

The emerging concern of the ineffectiveness of conventional antimicrobial agents, as well as the growing multidrug resistant strains, as a global threat, generated a true need for the exploration of natural alternatives, with a potent antibacterial potential to cure infectious diseases that were an increasing threat to human health [21,55]. Thus, the antibacterial impact of different parts of the plant, as well as their essential oils, have been greatly investigated for tremendous Gram-positive and Gram-negative bacterial strains, as summarized in Table 2, demonstrating that E. globulus is a promising antibacterial agent 
with enormous therapeutic applications. The efficiency of Eucalyptus essential oil, as well as plant part extracts, against bacterial species are attributed to the following:

Table 2. Antibacterial activities reported in different parts of E. globulus Labill.

\begin{tabular}{|c|c|c|c|c|}
\hline Plant Parts & Solvent Used & Method Used & Target Species & References \\
\hline Leaves & Essential oil & Agar diffusion technique & $\begin{array}{l}\text { Staphylococcus aureus CECT } 4459 \\
\text { Escherichia coli O157:H7 CECT } 4267\end{array}$ & [58] \\
\hline Aerial parts & Essential oil & Disc diffusion assay & $\begin{array}{l}\text { Salmonella enteritidis (CECT 4155) } \\
\text { Escherichia coli (CECT 4267) } \\
\text { Pseudomonas aeruginosa (CECT 110) } \\
\text { Staphylococcus aureus (CECT 239) } \\
\text { Enterococcus faecium (CECT 239) } \\
\text { Listeria monocytogenes (CECT 935) } \\
\text { Listeria monocytogenes EGD-e }\end{array}$ & [25] \\
\hline Leaves & Essential oil & $\begin{array}{c}\text { Agar disc } \\
\text { diffusion method }\end{array}$ & $\begin{array}{c}\text { Staphylococcus aureus ATCC } 25923 \\
\text { Escherichia coli ATCC } 25922 \\
\text { Pseudomonas aeruginosa ATCC } 27853 \\
\text { Phylococcus aureus } \\
\text { Escherichia coli } \\
\text { Pseudomonas aeruginosa } \\
\text { klebsiella pneumoniae } \\
\text { Proteus mirabilis } \\
\text { Streptococcus pyogenes } \\
\text { Morganella morganii } \\
\text { Providencia stuartii } \\
\text { Enterobacter cloacae } \\
\text { Acinetobacter baumannii } \\
\text { Citrobacter freundii } \\
\text { Salmonella infantis }\end{array}$ & [9] \\
\hline Leaves & Essential oil & $\begin{array}{l}\text { Agar disc diffusion and } \\
\text { dilution broth methods }\end{array}$ & $\begin{array}{c}\text { Escherichia coli } \\
\text { Staphylococcus aureus }\end{array}$ & [74] \\
\hline Leaves & Essential oil & Agar dilution method & Helicobacter pylori ATCC 700392 & [75] \\
\hline Leaves & $\begin{array}{l}\text { Methanol } \\
\text { extract }\end{array}$ & Cup-plate method & $\begin{array}{l}\text { Staphylococcus aureus } \\
\text { Bacillus subtilis }\end{array}$ & [60] \\
\hline Leaves & Ethyl acetate & Agar well diffusion method & $\begin{array}{c}\text { Lactobacillus acidophilus (MTCC-*447) } \\
\text { Lactobacillus casei (MTCC-1423) } \\
\text { Staphylococcus aureus (MTCC-890) } \\
\text { Streptococcus mutans (MTCC-96) }\end{array}$ & [19] \\
\hline Fruits & $\begin{array}{l}\text { Aqueous methanol } \\
\qquad(80 \%)\end{array}$ & Disc diffusion method & $\begin{array}{c}\text { Staphylococcus aureus ATCC } 6538 \\
\text { Bacillus subtilis ATCC } 6633 \\
\text { Klebsiella pneumoniae E } 47\end{array}$ & [73] \\
\hline Leaves & $\begin{array}{l}\text { Oil encapsulated } \\
\text { silica nanoparticle }\end{array}$ & Agar well diffusion method & Escherichia coli (ATCC 25922) & [29] \\
\hline Leaves & Essential oil & Cylinder plate method & $\begin{array}{c}\text { Bacillus subtilis } \\
\text { Escherichia coli } \\
\text { Staphylococcus aureus } \\
\text { Pseudomonas aeruginosa }\end{array}$ & [28] \\
\hline Stump & $\begin{array}{l}\text { n-hexane, ethanol, } \\
\text { methanol and } 75 \% \\
\text { aqueous ethanol }\end{array}$ & Disc diffusion assay & $\begin{array}{c}\text { Staphylococcus aureus ATCC } 25923 \text { Bacillus cereus } \\
\text { ATCC } 11778 \\
\text { Listeria monocytogenes LMG } 16779 \text { Enterococcus } \\
\text { faecalis ATCC } 29212 \\
\text { Escherichia coli ATCC } 25922 \text { Pseudomonas aeruginosa } \\
\text { ATCC } 27853 \\
\text { Klebsiella pneumoniae ATCC } 13883 \\
\text { S. aureus: SA 01/10, SA 02/10, SA 03/10 and SA } 08 \\
\text { S. aureus: MRSA 10/08 and MRSA } 12 / 08\end{array}$ & [57] \\
\hline
\end{tabular}


Table 2. Cont.

\begin{tabular}{ccccc}
\hline Plant Parts & Solvent Used & Method Used & Target Species & References \\
\hline Leaves & Methanolic extracts & Disk diffusion method & Pseudomonas aeruginosa & [2] \\
\hline Leaves & Essential oil & Agar diffusion method & Streptococcus mutans (ATCC 700610) & [1] \\
\hline Leaves & Essential oil & Agar well diffusion method & Staphylococcus aureus (MTCC 3160), Staphylococcus \\
& & epidermidis (MTCC 435) & Pseudomonas aeruginosa (MTCC 7453) \\
& & Klebsiella pneumonia (MTCC 4030) & [15] \\
\hline
\end{tabular}

Fusobacterium nucleatum ATCC 25586

Aggregatibacter actinomycetemcomitans ATCC 29522

Porphyromonas gingivalis ATCC 33277, ATCC 49417,

Leaves Essential oil Broth microdilution method HW24D1, and W83)

Streptococcus mutans ATCC 35668 ATCC 33535,

ATCC 25175

S. sobrinus ATCC 33478, ATCC 27607 ATCC 27352

\begin{tabular}{|c|c|c|c|c|}
\hline Leaves & $\begin{array}{l}\text { Essential oil } \\
\text { incorporated into } \\
\text { chitosan films }\end{array}$ & Agar diffusion assay & $\begin{array}{c}\text { Staphylococcus aureus } \\
\text { Escherichia coli } \\
\text { Pseudomonas aeruginosa } \\
\text { Klebsiella pneumonia }\end{array}$ & [59] \\
\hline Leaves & Essential oil & Agar diffusion method & $\begin{array}{c}\text { Salmonella typhi } \\
\text { Salmonella paratyphi } \\
\text { Salmonella typhimurium } \\
\text { Shigella species } \\
\text { Pseudomonas aeruginosa } \\
\text { Staphylococcus aureus } \\
\text { Escherichia coli }\end{array}$ & [14] \\
\hline $\begin{array}{l}\text { Leaves and } \\
\text { small branches }\end{array}$ & Essential oil & Disc diffusion assay & $\begin{array}{c}\text { Pseudomonas aeruginosa ATCC } 27853 \\
\text { E. coli ATCC } 25922 \\
\text { K. pneumoniae ATCC } 13883 \text { Salmonella Typhimurium } \\
\text { ATCC } 13311 \\
\text { Acinetobacter baumannii LMG } 1025 \text { Acinetobacter } \\
\text { baumannii LMG } 1041 \\
\text { P. aeruginosa PA 08 } \\
\text { P. aeruginosa PA 12/08 } \\
\text { E. coli EC 08 } \\
\text { K. pneumoniae KP } 08\end{array}$ & [13] \\
\hline Fruits & Essential oil & Agar diffusion test & $\begin{array}{c}\text { Staphylococcus aureus ATCC } 43300 \\
\text { Bacillus subtilis ATCC } 6633 \\
\text { Listeria innocua CLIP } 74915 \\
\text { Escherichia coli ATCC } 25922 \\
\text { Pseudomonas aeruginosa ATCC } 27853\end{array}$ & [44] \\
\hline Leaves & Essential oil & Disk infusion & $\begin{array}{c}\text { Escherichia coli ATCC } 25922 \text { Pseudomonas aeruginosa } \\
\text { ATCC } 27853 \text { Staphylococcus aureus ATCC } 25923\end{array}$ & [76] \\
\hline Leaves & $\begin{array}{l}\text { Aqueous, ethanol, } \\
\text { and methanol }\end{array}$ & Agar disc diffusion method & $\begin{array}{l}\text { Staphylococcus aureus (MTCC 3160) } \\
\text { Escherichia coli (MTCC 1655) Streptococcus mutans } \\
\text { (MTCC 890) }\end{array}$ & [30] \\
\hline Leaves & Aqueous ethanol & Serial dilution technique & $\begin{array}{c}\text { Listeria innocua (NCTC 10528) } \\
\text { Staphylococcus aureus (ATCC 6538) Escherichia coli } \\
\text { (ATCC 25922) Bacillus cereus (DSM 4313) } \\
\text { Pseudomonas aeruginosa (10145) Salmonella enteritidis } \\
\text { (ATCC 3076) }\end{array}$ & [54] \\
\hline Leaves & $\begin{array}{l}\text { Nanoemulsions } \\
\text { containing oil }\end{array}$ & Broth microdilution technique & Pseudomonas aeruginosa PA01 & [12] \\
\hline Aerial parts & Essential oil & Disk diffusion method & $\begin{array}{c}\text { Staphylococcus aureus ATCC } 6816 \\
\text { Staphylococcus aureus (MRSA) } \\
\text { Bacillus cereus ATCC } 14579 \text { Listeria monocytogenes } \\
\text { ATCC } 19115 \text { Enterococcus faecalis ATCC } 29212 \\
\text { Escherichia coli ATCC } 25922 \text { Klebsiella pneumoniae } \\
\text { CIP } 104727 \text { Salmonella enteridis DMB } 560\end{array}$ & [72] \\
\hline
\end{tabular}


Table 2. Cont.

\begin{tabular}{|c|c|c|c|c|}
\hline Plant Parts & Solvent Used & Method Used & Target Species & References \\
\hline Leaves & Essential oil & $\begin{array}{l}\text { Double-dilution micro-plate } \\
\text { assay }\end{array}$ & $\begin{array}{l}\text { E. coli } 1 \\
\text { E. coli } 2 \\
\text { S. aureus } 1 \\
\text { S. aureus } 2 \\
\text { P. aeruginosa } \\
\text { P. mirabilis }\end{array}$ & [16] \\
\hline Leaves & Essential oil & In vitro microdilution method & $\begin{array}{c}\text { Propionibacterium acnes ATCC } 6919 \\
\text { P. acnes ATCC } 11827 \\
\text { Staphylococcus aureus ATCC } 6538 \\
\text { S. epidermidis ATCC } 12228\end{array}$ & [10] \\
\hline Leaves & Essential oil & Agar diffusion test & $\begin{array}{c}\text { Enterococcus hiare (ATCC 10,541) } \\
\text { Baccilus licheniformis (ATCC 8480) } \\
\text { Staphyllococcus aureus (ATCC 6538) } \\
\text { Pseudomonas aeruginosa (ATCC 9027) } \\
\text { Serratia marcescens (ATCC 13,880) } \\
\text { Escherchia coli (ATCC 8739) }\end{array}$ & [77] \\
\hline Leaves & $\begin{array}{l}\text { Zinc oxide } \\
\text { nanoparticles from } \\
\text { essential oil of }\end{array}$ & Agar well diffusion method & $\begin{array}{c}\text { Staphylococcus aureus ATCC } 43300 \text { Staphylococcus } \\
\text { aureus ATCC } 25923 \text { Enterococcus faecalis ATCC } 29212 \\
\text { Escherichia coli ATCC } 25922 \\
\text { Klebsiella pneumoniae } \\
\text { Salmonella enteritidis ATCC } 13076 \text { Salmonella } \\
\text { typhimurium } \\
\text { Pseudomonas aeruginosa ATCC } 27853 \\
\text { Acinetobacter baumannii }\end{array}$ & [33] \\
\hline Leaves & Aqueous extract & Agar disk diffusion method & $\begin{array}{c}\text { Staphylococcus aureus ATCC } 6536 \text { Bacillus subtilis } \\
\text { ATCC } 6633 \text { Escherichia coli ATCC } 8739\end{array}$ & [55] \\
\hline Leaves & Essential oil & Broth microdilution method & $\begin{array}{c}\text { Staphylococus aureus ATCC } 25923 \\
\text { Streptococus pyogenes ATCC } 28422 \\
\text { Eschericha coli }\end{array}$ & [21] \\
\hline Leaves & Essential oil & Agar disc diffusion method & $\begin{array}{c}\text { Acetobacter aceti } \\
\text { Pseudomonas aeruginosa MTCC } 427 \\
\text { Escherichia coli MTCC } 40 \\
\text { Bacillus subtilis MTCC } 121 \text { Staphylococcus aureus } \\
\text { MTCC } 3160 \text { Saccharomyces cerevisiae }\end{array}$ & [31] \\
\hline
\end{tabular}

The extracted essential oil from fruits exerted pronounced antibacterial potency against tested multidrug-resistant bacteria. Furthermore, the combination of 1,8-cineole and aromadendrene from fruit oils produced a higher inhibition through an additive and synergistic effect against methicillin-resistant Staphylococcus aureus, Streptococcus pyogenes, and Bacillus subtilis, as compared to using a single compound [43]. The antibacterial efficacy was ascribed to the highest percentage of oxygenated monoterpenes $(87.32 \%)$ in Eucalyptus leaf oil, and the synergism also resulted from other minor components [9]. The antimicrobial effects of the methanolic extract from leaves, against $S$. aureus and B. subtilis, could be attributed to the existence of tannins and saponins [60]. Similarly, leaf extracts proved the anticariogenic activity, due to the existence of sesquiterpene alpha-farnesene that would lead to an advancement of effective drugs for the treatment of dental caries [19].

The greatest antibacterial activity was obtained from the synergism between E. globulus essential oil or leaf extracts and antibiotics toward P. aeruginosa [2]. Additionally, Goldbeck et al. [1] observed a synergism effect as a result of the combination between E. globulus and E. urograndis essential oils against Streptococcus mutans. Furthermore, the highest antibacterial activity was correlated with the elevated concentration of 1,8-cineole (71\%) in E. globulus, as compared to E. urograndis (36\%), which supported the potential usage of E. globulus essential oil, through its incorporation into biodegradable films, as an environmentally benign strategy to control S. mutans, as an important oral pathogen.

As outlined by Luís et al. [13], the synergistic action of essential oil with the presence of chloramphenicol, ciprofloxacin, and tetracycline toward Acinetobacter baumannii strains was observed. On the other hand, there was no synergistic activity between the combination 
of essential oil with cefoperazone and piperacillin against the aforementioned strains. The powerful antibacterial efficacy was correlated with the high content of $\alpha$-pinene and 1,8-cineole in the essential oil extracted from the leaves [14]. Notwithstanding, Quatrin et al. [12] reported that nano-emulsions contained a low amount of Eucalyptus essential oil $(5 \%)$ and were ineffective against the Gram-negative bacterium, which was generally found in immunocompromised patients. Interestingly, synergism was detected in the combination of ampicillin and Eucalyptus essential oil against Methicillin-resistant Staphylococcus aureus, which accordingly brought down the MIC value of the antibiotic by 32-fold and the MIC of the essential oil to half against $S$. aureus. This combination also reduced the essential oil toxicity of the healthy cells [72].

The methanol extract of leaves displayed a promising antibacterial activity against S. mutans, S. aureus, and E. coli, as compared to the aqueous and ethanol leaf extracts, which was attributable to the extraction of highly diverse components by methanol, with respect to other extracts [30]. The Eucalyptus aqueous ethanol leaf extract showed a similar trend and exhibited antibacterial activity against the tested species. The authors attributed the additive or synergistic effect as being related to the existence of various bioactive molecules [54]. The aqueous extract of E. globulus leaves showed the same mode of action as Ampicillin against $S$. aureurs. Furthermore, the extract showed a significant inhibitory action against $S$. aureus and B. subtilis as compared to Gentamicin, which could explain the profound amount of polyphenols and flavonoids in the extract [55].

Eucalyptus essential oil and its main component (1,8-cineole) exerted a potent antibacterial activity against the development of the biofilm produced by methicillin-resistant S. aureus strains [78]. Interestingly, Obeizi et al. [33] proved that the $\mathrm{ZnO}$ nanoparticles biosynthesized from the leaf essential oil displayed effective anti-biofilm activity against S. aureus ATCC 25923 and P. aeruginosa ATCC 27853, which are known for their elevated biofilm formation potential that will help to overcome antibiotic resistance resulting from a bacterial biofilm, which is considered the major reason for nosocomial infection transition. The antimicrobial potential of the Eucalyptus leaf essential oil may be due to the synergistic effects of the polyphenolics [31].

Generally, Gram-negative bacterial cells were more resistant to the presence of Eucalyptus extracts as well as its essential oil than the Gram-positive ones [20,25,58,72]. In addition, the fruit extract showed antibacterial activity only against the Gram-positive bacteria, which was due to its richness in phenolic compounds, even as no activity was detected against the Gram-negative bacteria, which could be ascribed to their outer lipopolysaccharide membrane [73].

\subsection{Antifungal Activity}

Few studies have been conducted on the impact of E. globulus leaves and stumps as antifungal agents (Table 3 ) to eradicate fungal infections that are antibiotic-resistant, as a major challenge worldwide, for example, in the case of Candida spp. and other fungal species. Furthermore, due to the growing number of cases infected by the Candida spp. and the increased risk of drug resistance, finding a new therapeutic strategy is considered to be of fundamental importance. The induced antifungal efficacy has been attributed to the richness of the plant parts with diverse phytochemical constituents (Table 1) that represent a cost-effective approach to combat fungal infections.

E. globulus essential oil showed a potent anti-candidal efficacy, indicating that the oil is a potential candidate for mouth wash applications [32]. Similarly, Eucalyptus essential oil surpassed the antifungal nystatin (a drug utilized to control fungal infections on the skin, mouth, vagina, and intestinal tract) twice over, in the antifungal efficacy against $C$. albicans, which could likely be ascribed to the high content of 1,8 -cineole $(85.8 \%)$ in the leaf essential oil [9]. Nanoemulsions containing E. globulus essential oil that was commercially acquired possessed antifungal and antibiofilm activities against $C$. albicans, which were the main microorganisms responsible for initiating fungal infections globally [12]. These findings were due to the nanoencapsulation-enhanced functionality of the essential oil via the 
protection of essential oil components, as well as the reduced size of the nanoemulsions that resulted in rapid penetration.

Table 3. Antifungal activities reported in different parts of E. globulus Labill.

\begin{tabular}{|c|c|c|c|c|}
\hline Plant Parts & Solvent Used & Method Used & Target Species & References \\
\hline Leaves & Essential oil & Micro dilution method & $\begin{array}{c}\text { Candida albicans ATCC } 90028 \\
\text { Candida albicans 15B }\end{array}$ & [32] \\
\hline leaves & Essential oil & Agar-well diffusion method & Candida spp. & {$[65]$} \\
\hline Leaves & Essential oil & Broth microdilution assay & Candida albicans ATCC 10231 & [9] \\
\hline Leaves & Methanol extract & Cup-plate method & Trichophytor rubrum & {$[60]$} \\
\hline Leaves & Essential oil & Cylinder plate method & $\begin{array}{l}\text { Aspergillus niger } \\
\text { Candida albicans }\end{array}$ & [28] \\
\hline Stump & $\begin{array}{l}\text { n-hexane, ethanol, } \\
\text { methanol, and } 75 \% \\
\text { aqueous ethanol }\end{array}$ & Disc diffusion assay & $\begin{array}{c}\text { Candida albicans ATCC } 90028 \\
\text { Candida tropicalis ATCC } 750\end{array}$ & [57] \\
\hline Leaves & $\begin{array}{l}\text { Essential oil } \\
\text { incorporated into } \\
\text { chitosan films }\end{array}$ & Agar diffusion assay & $\begin{array}{l}\text { Candida albicans } \\
\text { Candida parapsilosis }\end{array}$ & [59] \\
\hline Leaves & Essential oil & Agar diffusion method & $\begin{array}{l}\text { Trichophyton spp. } \\
\text { Aspergillus spp. }\end{array}$ & [14] \\
\hline Leaves & $\begin{array}{l}\text { Nanoemulsions } \\
\text { containing oil }\end{array}$ & Broth microdilution technique & $\begin{array}{l}\text { C. albicans (ATCC 14053) } \\
\text { C. tropicalis (ATCC 66029) } \\
\text { C. glabrata (ATCC 66032) }\end{array}$ & [12] \\
\hline Aerial parts & Essential oil & Disk diffusion assay & Candida albicans ATCC 10231 & [72] \\
\hline Leaves & Essential oil & $\begin{array}{l}\text { Double-dilution micro-plate } \\
\text { assay }\end{array}$ & $\begin{array}{l}\text { C. albicans1 } \\
\text { C. albicans2 }\end{array}$ & [16] \\
\hline Leaves & $\begin{array}{l}\text { Zinc oxide } \\
\text { nanoparticles from } \\
\text { essential oil }\end{array}$ & Agar well diffusion method & Candida albicans & [33] \\
\hline
\end{tabular}

The essential oil from the Tunisian Eucalyptus aerial parts proved to have a potent antifungal efficacy against $C$. albicans that was greater than the antifungal (Amphotericin B), especially the essential oil obtained in the fruiting stage, rather than the essential oil obtained in the vegetative and full flowering stages. This was probably because of the defense mechanisms of the plant during fruit formation or the variation in oil components during the different growth stages, as the oil contains considerable amounts of $\alpha$-pinene and $p$-cymene with a high essential oil yield during the final developmental stage. Furthermore, the combined application of Eucalyptus essential oil with amphotericin B showed a great decline in the MIC value of Eucalyptus essential oil alone against C. albicans, from 1000 to $31.25 \mu \mathrm{g} / \mathrm{mL}$ in the case of a combination [72]. Similarly, Bogavac et al. [16] showed the potent antifungal efficacy of essential oil as a promising alternative against vaginal C. albicans strains that were multidrug-resistant to conventional antifungals.

\section{Eco-Friendly Approaches for Application of E. globulus}

The efficiency of E. globulus for protecting plants from undesirable impacts of heavy metals and invasive plants as well as insects have been recognized as an efficient alternative for controlling weed growth, insects, and extracting pollutants from contaminated soil. This could be considered as an environmentally benign method.

For enhancing the ability of plants for phytoextraction, Luo et al. [79] recommended the replanting of E. globulus as an appropriate method for removing cadmium from the contaminated soil via root removal during every harvest, rather than following the coppicing system, regardless of the elevated cost of replanting. This also reduced the phytoremedia- 
tion time, considering that the greatest amount of heavy metals will be absorbed by the Eucalyptus roots as a non-metabolically active component. Additionally, in the observations outlined by Luo et al. [79-81], E. globulus had potent heavy metal phytoremediation due to its fast growth and high above-ground biomass, as well as its ability to decline the physiological damage through aggregation of toxic materials in the less sensitive parts, as compared to the metabolically active parts. Likewise, the E. globulus trees could accumulate cadmium $(\mathrm{Cd})$ and lead $(\mathrm{Pb})$, which made them potential candidates for the efficient capture of heavy metals from contaminated areas [82]. In recent times, Reboredo et al. [17] stated that $E$. globulus was able to remove arsenic from plantations close to mining activities and its root system was considered to be the greatest organ for accumulation, although translocation to the above-ground organs is poor. This promoted the phytoremediation efficacy of Eucalyptus plants as cost effective and provided an efficient process for removing heavy metals from contaminated lands; thus, it could help to counteract the limitations of conventional methods in the heavy metal elimination process.

For the phototoxic effect of E. globulus, the leaf methanolic extract had greater allelopathic activity, and accordingly, it diminished the percentage of germination, the germination rate, root and shoot growth, and the fresh and dry weights of eggplant, than the other extracts used [49]. In addition, Morsi and Abdelmigid [51] proved the allelopathic activity of the Eucalyptus aqueous leaf extract via the inhibition of seed germination, and the seedling growth of the Hordeum vulgare plants was ascribed to the presence of phytotoxic phenolics in the leaf extract.

Implementation of the Eucalyptus allelopathic properties in weed management will ameliorate the herbicide resistance resulting from the excessive application of synthetic herbicides; additionally, this strategy will maximize crop production by suppressing weeds that compete with crops for the same resources. With regard to this concern, Puig et al. $[83,84]$ stated that the incorporation of E. globulus residues into the soil as green manure will diminish synthetic herbicide usage, especially in organic farming, to control weeds, as an environmental friendly practice. A leaf extract with an allelopathic potential can be used as a natural promising bioherbicide to inhibit both broad and narrow leaf weeds associated with the pea plant [50]. Furthermore, the leaf aqueous extract adversely influences the germination and seedling growth of teff and barley plants, as compared to the juvenile stem and root extracts [85]. Therefore, the allelopathic compatibility between crops and Eucalyptus trees must be essentially checked to avoid the potential adverse effects of trees on the associated crops. Additionally, the aqueous extract of the oven-dried leaves has a herbicidal potential as a biocide against the widespread weed of Portulaca oleracea L., which is attributable to the existence of a significant amount of allelochemicals [86]. The above-mentioned results recommend that the bioactive compounds present in Eucalyptus plants must be further investigated in weed control, as bioherbicides, with possible commercial applications.

The essential oil of Eucalyptus is considered to be a good ecological choice for maintaining the vase-life quality of "Carola" roses. This will help to overcome the use of toxic pesticides, as a routine procedure after harvest, of rose growers, which causes an undesirable impact on the environment and humans as well, as it can increase pathogen resistance [87]. In addition, the insecticidal activity of Eucalyptus essential oil has been previously assessed against the housefly [36], Musca domestica L. [38,88], Culexpipiens [37], and Myzuspersicae [66]. Furthermore, Eucalyptus essential oil and $\mathrm{Co}_{2}$ extract showed chronic toxicity and antifeedant efficiency against Leptinotarsa decemlineata [6]. Additionally, the nanocapsule formulation of hydroalcoholic leaf extracts exhibited repellent and biocidal activities against Aphis fabae [89]. Therefore, essential oil and plant extracts could be used as botanical insecticides, repellents, as well as fumigants, instead of chemical insecticides, due to their non-phytotoxic activity. Seemingly, the use of these natural insecticides is a promising approach for dealing with the emerging problem of insect resistance, potential toxicity to non-target insects as well as the environmental pollution caused due to excessive insecticide applications. On account of the increasing advocacy of organic agriculture in 
many countries, including Egypt, additional investigations on the possibility of using Eucalyptus plant parts, as well as their essential oils, in organic farming should be undertaken to enrich the quality of agricultural products, which will be reflected in the environment and human health.

\section{Future Perspectives}

The above-mentioned encouraging results support the use of different E. globulus plant part extracts, as well as their essential oils, as antioxidant and antimicrobial agents that stimulate further clinical trials, which should be implemented to confirm the aforementioned findings for further medical purposes. For a deep understanding of all the bioactive compound mechanisms involved in all the studied bioactivities, further trials should be implemented to explore the synergistic or antagonistic interactions among the complex mixtures of essential oils. In addition, the mechanism of action after the combination of oils and conventional antibiotics, which may influence multiple targets at the same time, should be investigated more thoroughly.

Additional studies are warranted to counteract the poor penetration of natural antimicrobial agents into the microorganism biofilm matrix, which can be achieved through nanocarriers. However, in the case of using biosynthesized nanoparticles, further investigation will be needed to demonstrate the impact of their cytotoxicity, with emphasis on optimizing the separation processes of the phenolic compounds, with detailed chemical characterization for possible extract quality improvement. Taking into consideration implementation of the available information on the effect of Eucalyptus essential oil and its extracts on the antimicrobial potency, it will be considered a great alternative to combat the resistance problem. Furthermore, the potent antimicrobial, herbicidal, and insecticidal activities of essential oil and plant parts should be transformed into commercial products.

Author Contributions: Conceptualization, A.Y.S. and M.A.G.; writing—original draft preparation, A.Y.S.; writing-review and editing, A.Y.S. and M.A.G. All authors have read and agreed to the published version of the manuscript.

Funding: This research received no external funding.

Institutional Review Board Statement: Not applicable.

Informed Consent Statement: Not applicable.

Data Availability Statement: Not applicable.

Conflicts of Interest: The authors declare no conflict of interest.

\section{References}

1. Goldbeck, J.C.; Do Nascimento, J.E.; Jacob, R.G.; Fiorentini, M.Â.; Da Silva, W.P. Bioactivity of essential oils from Eucalyptus globulus and Eucalyptus urograndis against planktonic cells and biofilms of Streptococcus mutans. Ind. Crops Prod. 2014, 60, 304-309. [CrossRef]

2. Pereira, V.; Dias, C.; Vasconcelos, M.C.; Rosa, E.; Saavedra, M.J. Antibacterial activity and synergistic effects between Eucalyptus globulus leaf residues (essential oils and extracts) and antibiotics against several isolates of respiratory tract infections (Pseudomonas aeruginosa). Ind. Crops Prod. 2014, 52,1-7. [CrossRef]

3. Mulyaningsih, S.; Sporer, F.; Reichling, J.; Wink, M. Antibacterial activity of essential oils from Eucalyptus and of selected components against multidrug-resistant bacterial pathogens. Pharm. Biol. 2011, 49, 893-899. [CrossRef] [PubMed]

4. Joshi, A.; Sharma, A.; Bachheti, R.K.; Pandey, D.P. A comparative study of the chemical composition of the essential oil from Eucalyptus globulus growing in Dehradun (India) and around the world. Orient. J. Chem. 2016, 32, 331-340. [CrossRef]

5. Boukhatem, M.N.; Amine, F.M.; Kameli, A.; Saidi, F.; Walid, K.; Mohamed, S.B. Quality assessment of the Essential oil from Eucalyptus globulus Labill of Blida (Algeria) origin. Int. Lett. Chem. Phys. Astron. 2014, 17, 303-315. [CrossRef]

6. Topiar, M.; Sajfrtova, M.; Pavela, R.; Machalova, Z. Comparison of fractionation techniques of $\mathrm{CO}_{2}$ extracts from Eucalyptus globulus-Composition and insecticidal activity. J. Supercrit. Fluids 2015, 97, 202-210. [CrossRef]

7. Fabiyi, O.A.; Atolani, O.; Olatunji, G.A. Toxicity effect of Eucalyptus globulus on Pratylenchus spp. of Zea mays. Sarhad J. Agric. 2020, 36, 1244-1253. 
8. Derwich, E.; Benziane, Z.; Chabir, R.; Bouseta, A. Antifungal activity and gas chromatography coupled with mass spectrometry (GC-MS) leaf oil analysis of essential oils extracted from Eucalyptus globulus (Myrtaceae) of north centre region of Morocco. Afr. J. Pharm. Pharmacol. 2013, 7, 1157-1162. [CrossRef]

9. Damjanović-Vratnica, B.; Dakov, T.; Šuković, D.; Damjanović, J. Antimicrobial effect of essential oil isolated from Eucalyptus globulus Labill. from Montenegro. Czech J. Food Sci. 2011, 29, 277-284. [CrossRef]

10. Göger, G.; Karaca, N.; Altınbaşak, B.B.; Demirc, B.; Demirci, F. In vitro antimicrobial, antioxidant and anti-inflammatory evaluation of Eucalyptus globulus essential oil. Nat. Volatiles Essent. Oils 2020, 7, 1-11.

11. Abdossi, V.; Moghaddam, E.Y.; Hadipanah, A. Chemical Composition of Eucalyptus globulus grown in Iran. Biol. Forum 2015, 7, 322-324.

12. Quatrin, P.M.; Verdi, C.M.; de Souza, M.E.; de Godoi, S.N.; Klein, B.; Gundel, A.; Wagner, R.; de Almeida Vaucher, R.; Ourique, A.F.; Santos, R.C.V. Antimicrobial and antibiofilm activities of nanoemulsions containing Eucalyptus globulus oil against Pseudomonas aeruginosa and Candida spp. Microb. Pathog. 2017, 112, 230-242. [CrossRef]

13. Luís, Â.; Duarte, A.; Gominho, J.; Domingues, F.; Duarte, A.P. Chemical composition, antioxidant, antibacterial and anti-quorum sensing activities of Eucalyptus globulus and Eucalyptus radiata essential oils. Ind. Crops Prod. 2016, 79, 274-282. [CrossRef]

14. Mekonnen, A.; Yitayew, B.; Tesema, A.; Taddese, S. In vitro antimicrobial activity of essential oil of Thymus schimperi, Matricaria chamomilla, Eucalyptus globulus and Rosmarinus officinalis. Int. J. Microbiol. 2016. [CrossRef] [PubMed]

15. Bachheti, R.K. Chemical composition and antibacterial activity of the essential oil from the leaves of Eucalyptus globulus collected from Haramaya University, Ethiopia. Der Pharma Chem. 2015, 7, 209-214.

16. Bogavac, M.; Tešanović, K.; Marić, J.; Jovanović, M.; Karaman, M. Antimicrobial activity and toxicity of Eucalyptus globulus Labill. essential oil against vaginal microorganisms. Trends Phytochem. Res. 2019, 3, 201-206.

17. Reboredo, F.H.; Pelica, J.; Lidon, F.C.; Pessoa, M.F.; Silva, M.M.; Guerra, M.; Leitão, R.; Ramalho, J.C. The tolerance of Eucalyptus globulus to soil contamination with arsenic. Plants 2021, 10, 627. [CrossRef] [PubMed]

18. Troncoso, C.; Becerra, J.; Bittner, M.; Perez, C.; Sáez, K.; Sánchez-Olate, M.; Ríos, D. Chemical defense responses in Eucalyptus globulus (Labill) plants. J. Chil. Chem. Soc. 2011, 56, 768-770. [CrossRef]

19. Ishnava, K.B.; Chauhan, J.B.; Barad, M.B. Anticariogenic and phytochemical evaluation of Eucalyptus globules Labill. Saudi J. Biol. Sci. 2013, 20, 69-74. [CrossRef] [PubMed]

20. Harkat-Madouri, L.; Asma, B.; Madani, K.; Said, Z.B.-O.S.; Rigou, P.; Grenier, D.; Allalou, H.; Remini, H.; Adjaoud, A.; Boulekbache-Makhlouf, L. Chemical composition, antibacterial and antioxidant activities of essential oil of Eucalyptus globulus from Algeria. Ind. Crops Prod. 2015, 78, 148-153. [CrossRef]

21. Pino, J.A.; Moncayo-molina, L.; Spengler, I.; Pérez, J.C. Chemical composition and antibacterial activity of the leaf essential oil of Eucalyptus globulus Labill. from two highs of the canton Cañar, Ecuador. Rev. CENIC Ciencias Quimicas 2021, 52, 26-33.

22. Almas, I.; Innocent, E.; Machumi, F.; Kisinza, W. Chemical composition of essential oils from Eucalyptus globulus and Eucalyptus maculata grown in Tanzania. Sci. Afr. 2021, 12, e00758.

23. Tomazoni, E.Z.; Pauletti, G.F.; da Silva Ribeiro, R.T.; Moura, S.; Schwambach, J. In vitro and in vivo activity of essential oils extracted from Eucalyptus staigeriana, Eucalyptus globulus and Cinnamomum camphora against Alternaria solani Sorauer causing early blight in tomato. Sci. Hortic. 2017, 223, 72-77. [CrossRef]

24. Kassahun, A.; Feleke, G. Chemical composition and physico-chemical analysis of Eucalyptus globulus leave and oil. Sci. J. Chem. 2019, 7, 36-38. [CrossRef]

25. Ait-ouazzou, A.; Conchello, P. Chemical composition and antimicrobial activity of essential oils of Thymus algeriensis, Eucalyptus globulus and Rosmarinus officinalis from Morocco. J. Sci. Food Agric. 2011, 91, 2643-2651. [CrossRef]

26. Benabdesslem, Y.; Hachem, K.; Mébarki, M. Chemical composition of the essential oil from the leaves of Eucalyptus globulus Labill. growing in southwest Algeria. J. Essent. Oil-Bearing Plants 2020, 23, 1154-1160. [CrossRef]

27. Akolade, J.O.; Olajide, O.O.; Afolayan, M.O.; Akande, S.A.; Idowu, D.I.; Orishadipe, A.T. Chemical composition, antioxidant and cytotoxic effects of Eucalyptus globulus grown in north-central Nigeria. J. Nat. Prod. Plant Resour. 2012, 2, 1-8.

28. Dixit, A.; Rohilla, A.; Dixit, J.; Singh, V. Antimicrobail activity of volatile oil of Eucalyptus globulus Labill. Int. J. Adv. Pharm. Biol. Chem. 2014, 3, 384-387.

29. Dohare, S.; Dubey, S.D.; Kalia, M.; Verma, P.; Pandey, H.; Singh, N.K.; Agarwal, V. Anti-biofilm activity of Eucalyptus globulus oil encapsulated silica nanoparticles against E. coli biofilm. Int. J. Pharm. Sci. Res. 2014, 5, 5011-5016.

30. Jamil, K.; Asmuddin, M.; Ranawat, B.; Rao, C. Estimation of antibacterial activity of plants extracts from Phyllanthus emblica, Terminalia chebula and Eucalyptus globulus against oral pathogens. Int. J. Dent. Oral Heal 2017, 3, 100-104. [CrossRef]

31. Sharma, A.D.; Farmaha, M.; Kaur, I.; Singh, N. Phytochemical analysis using GC-FID, FPLC fingerprinting, antioxidant, antimicrobial, anti- inflammatory activities analysis of traditionally used Eucalyptus globulus essential oil. Drug Anal. Res. 2021, 5, 26-38. [CrossRef]

32. Noumi, E.; Snoussi, M.; Bakhrouf, A. In vitro effect of Melaleuca alternifolia and Eucalyptus globulus essential oils on mycelia formation by oral Candida albicans strains. Afr. J. Microbiol. Res. 2010, 4, 1332-1336.

33. Obeizi, Z.; Benbouzid, H.; Ouchenane, S.; Yılmaz, D.; Culha, M.; Bououdina, M. Biosynthesis of Zinc oxide nanoparticles from essential oil of Eucalyptus globulus with antimicrobial and anti-biofilm activities. Mater. Today Commun. 2020, $25,101553$. [CrossRef] 
34. Usman, L.A.; Oguntoye, O.S.; Ismaeel, R.O. Effect of seasonal variation on chemical composition, antidiabetic and antioxidant potentials of leaf essential oil of Eucalyptus globulus L. J. Essent. Oil Bear. Plants 2020, 23, 1314-1323. [CrossRef]

35. Jerbi, A.; Derbali, A.; Elfeki, A.; Kammoun, M. Essential oil composition and biological activities of Eucalyptus globulus leaves extracts from Tunisia. J. Essent. Oil-Bearing Plants 2017, 20, 438-448. [CrossRef]

36. Ebadollahi, A.; Safaralizadeh, M.H.; Pourmirza, A.A.; Ghosta, Y. Contact and fumigant toxicity of essential oils of Lavandula stoechas L. and Eucalyptus globulus Labill grown in Iran against Lasioderma serricorne F. Biharean Biol. 2010, 4, 31-36.

37. Elzayyat, E.; Elleboudy, N.; Moustafa, A.; Ammar, A. Insecticidal, oxidative, and genotoxic activities of Syzygium aromaticum and Eucalyptus globulus on Culex pipiens adults and larvae. Turk. Parazitol. Derg 2018, 42, 213-222. [CrossRef]

38. Kumar, P.; Mishra, S.; Malik, A.; Satya, S. Compositional analysis and insecticidal activity of Eucalyptus globulus (family: Myrtaceae) essential oil against housefly (Musca domestica). Acta Trop. 2012, 122, 212-218. [CrossRef]

39. Madreseh-ghahfarokhi, S.; Pirali, Y.; Dehghani-samani, A.; Dehghani-samani, A. The insecticidal and repellent activity of ginger (Zingiber officinale) and eucalyptus (Eucalyptus globulus) essential oils against Culex theileri Theobald, 1903 (Diptera: Culicidae). Ann. Parasitol. 2018, 64, 351-360. [PubMed]

40. Dehghani-Samani, A.; Madreseh-Ghahfarokhi, S.; Dehghani-Samani, A.; Pirali-Kheirabadi, K. Acaricidal and repellent activities of essential oil of Eucalyptus globulus against Dermanyssus gallinae (Acari: Mesostigmata). J. HerbMed Pharmacol. 2015, 4, 81-84.

41. Taur, D.J.; Kulkarni, V.B.; Patil, R.Y. Chromatographic evaluation and anthelmintic activity of Eucalyptus globulus oil. Pharmacogn. Res. 2010, 2, 125-127. [CrossRef] [PubMed]

42. Vigo, E.; Cepeda, A.; Perez-Fernandez, R.; Gualillo, O. In-vitro anti-inflammatory effect of Eucalyptus globulus and Thymus vulgaris: Nitric oxide inhibition in J774A. 1 murine macrophages. J. Pharm. Pharmacol. 2004, 56, 257-263. [CrossRef]

43. Mulyaningsih, S.; Sporer, F.; Zimmermann, S.; Reichling, J.; Wink, M. Synergistic properties of the terpenoids aromadendrene and 1,8-cineole from the essential oil of Eucalyptus globulus against antibiotic-susceptible and antibiotic-resistant pathogens. Phytomedicine 2010, 17, 1061-1066. [CrossRef]

44. Bey-Ould Si Said, Z.; Haddadi-Guemghar, H.; Boulekbache-Makhlouf, L.; Rigou, P.; Remini, H.; Adjaoud, A.; Khoudja, N.K.; Madani, K. Essential oils composition, antibacterial and antioxidant activities of hydrodistillated extract of Eucalyptus globulus fruits. Ind. Crops Prod. 2016, 89, 167-175. [CrossRef]

45. Ferreira, C.d.S.; Pereyra, A.; Patriarca, A.; Mazzobre, M.F.; Polak, T.; Abram, V.; Buera, M.P.; Ulrih, N.P. Phenolic compounds in extracts from Eucalyptus globulus leaves and Calendula officinalis flowers. J. Nat. Prod. Resour. 2016, 2, 53-57.

46. Nile, S.H.; Keum, Y.S. Chemical composition, antioxidant, anti-inflammatory and antitumor activities of Eucalyptus globulus Labill. Indian J. Exp. Biol. 2018, 56, 734-742.

47. Ita, B.N. Antioxidant activity of Eucalyptus globulus Labill root extracts. J. Pharmacogn. Phytochem. 2020, 9, 190-194.

48. Tola, A.T.; Egigu, M.C.; Egdu, B.H. Bio-efficacy of crude leaf extracts of Eucalyptus globulus against in vitro and in vivo growth of chocolate spot (Botrytis fabae Sard.) of Faba bean (Vicia faba L.). Plant 2016, 4, 37-44. [CrossRef]

49. Dejam, M.; Khaleghi, S.K.; Ataollahi, R. Allelopathic effects of Eucalyptus globulus Labill. on seed germination and seedling growth of eggplant (Solanum melongena L.). Int. J. Farming Allied Sci. 2014, 3, 81-86.

50. El-Rokiek, K.G.; Saad El-Din, S.A. Allelopathic activity of Eucalyptus globulus leaf water extract on Pisum sativum growth, yield and associated weeds. Middle East J. Appl. Sci. 2017, 07, 907-913.

51. Morsi, M.M.; Abdelmigid, H.M. Allelopathic activity of Eucalyptus globulus leaf aqueous extract on Hordeum vulgare growth and cytogenetic behaviour. Aust. J. Crop Sci. 2016, 10, 1551-1556. [CrossRef]

52. Ajilore, B.S.; Oluwadairo, T.O.; Olorunnisola, O.S.; Fadahunsi, O.S.; Adegbola, P.I. GC-MS analysis, toxicological and oral glucose tolerance assessments of methanolic leaf extract of Eucalyptus globulus. Futur. J. Pharm. Sci. 2021, 7, 162. [CrossRef]

53. Narasimha, V.R.; Latha, T.S.; Pallu, R.; Panati, K.; Narala, V.R. Anticancer activities of biogenic silver nanoparticles targeting apoptosis and inflammatory pathways in colon cancer cells. J. Clust. Sci. 2021. [CrossRef]

54. Gullón, B.; Gullón, P.; Lú-Chau, T.A.; Moreira, M.T.; Lema, J.M.; Eibes, G. Optimization of solvent extraction of antioxidants from Eucalyptus globulus leaves by response surface methodology: Characterization and assessment of their bioactive properties. Ind. Crops Prod. 2017, 108, 649-659. [CrossRef]

55. Bencheikh, D.; Gueddah, A.; Soualat, K.; Ben-aissi, H.; Benslama, A.; Harrar, A.; Khennouf, S. Polyphenolic contents, antioxidant and antibacterial activities of aqueous extracts of Eucalyptus globulus L. and Trigonella foenum-greacum L. J. Appl. Biol. Sci. 2021, 15, 53-63.

56. González-Burgos, E.; Liaudanskas, M.; Viškelis, J.; Žvikas, V.; Janulis, V.; Gómez-Serranillos, M.P. Antioxidant activity, neuroprotective properties and bioactive constituents analysis of varying polarity extracts from Eucalyptus globulus leaves. J. Food Drug Anal. 2018, 26, 1293-1302. [CrossRef]

57. Luís, A.; Neiva, D.; Pereira, H.; Gominho, J.; Domingues, F.; Duarte, A.P. Stumps of Eucalyptus globulus as a source of antioxidant and antimicrobial polyphenols. Molecules 2014, 19, 16428-16446. [CrossRef]

58. Djenane, D.; Yangüela, J.; Amrouche, T.; Boubrit, S.; Boussad, N.; Roncalés, P. Chemical composition and antimicrobial effects of essential oils of Eucalyptus globulus, Myrtus communis and Satureja hortensis against Escherichia coli O157:H7 and Staphylococcus aureus in minced beef. Food Sci. Technol. Int. 2011, 17, 505-515. [CrossRef]

59. Hafsa, J.; ali Smach, M.; Ben Khedher, M.R.; Charfeddine, B.; Limem, K.; Majdoub, H.; Rouatbi, S. Physical, antioxidant and antimicrobial properties of chitosan films containing Eucalyptus globulus essential oil. LWT Food Sci. Technol. 2016, 68, 356-364. [CrossRef] 
60. Obiorah, S.; Eze, E.; Obiorah, D.; Orji, N.; Umedum, C. Phytochemical and antimicrobial studies on the extracts from leaves of Cajanus cajan and Eucalyptus globulus. In Proceedings of the International Conference on Environment, Chemistry and Biology, Singapore, 17-18 March 2012; Volume 49, pp. 192-197.

61. Boulekbache-makhlouf, L.; Slimani, S.; Madani, K. Antioxidant effects and phytochemical analysis of crude and chromatographic fractions obtained from Eucalyptus globulus bark. Afr. J. Biotechnol. 2012, 11, 10048-10055. [CrossRef]

62. Rodrigues, V.H.; de Melo, M.M.R.; Portugal, I.; Silva, C.M. Extraction of Eucalyptus leaves using solvents of distinct polarity. Cluster analysis and extracts characterization. J. Supercrit. Fluids 2018, 135, 263-274. [CrossRef]

63. De Melo, M.M.R.; Oliveira, E.L.G.; Silvestre, A.J.D.; Silva, C.M. Supercritical fluid extraction of triterpenic acids from Eucalyptus globulus bark. J. Supercrit. Fluids 2012, 70, 137-145. [CrossRef]

64. Domingues, R.M.A.; Sousa, G.D.A.; Freire, C.S.R.; Silvestre, A.J.D.; Neto, C.P. Eucalyptus globulus biomass residues from pulping industry as a source of high value triterpenic compounds. Ind. Crops Prod. 2010, 31, 65-70. [CrossRef]

65. Noumi, E.; Snoussi, M.; Hajlaoui, H.; Trabelsi, N.; Ksouri, R.; Valentin, E.; Bakhrouf, A. Chemical composition, antioxidant and antifungal potential of Melaleuca alternifolia(tea tree) and Eucalyptus globulus essential oils against oral Candida species. J. Med. Plants Res. 2011, 5, 4147-4156.

66. Khoshraftar, Z.; Safekordi, A.A.; Shamel, A.; Zaefizadeh, M. Synthesis of natural nanopesticides with the origin of Eucalyptus globulus extract for pest control. Green Chem. Lett. Rev. 2019, 12, 286-298. [CrossRef]

67. Vazquez, G.; Santos, J.; Freire, M.S.; Antorrena, G.; Gonza'lez-Alvarez, J. Extraction of antioxidants from eucalyptus (Eucalyptus globulus) bark. Wood Sci. Technol. 2012, 46, 443-457. [CrossRef]

68. Sharma, A.D.; Kaur, I. By-product hydrosol of Eucalyptus globulus essential oil distillation as source of botanical insecticides: Wealth from waste. Not. Sci. Biol. 2021, 13, 10854. [CrossRef]

69. Mota, I.; Pinto, P.C.R.; Novo, C.; Sousa, G.; Guerreiro, O.; Guerra, Â.R.; Duarte, M.F.; Rodrigues, A.E. Eucalyptus globulus bark as source of polyphenolic compounds with biological activity. In Proceedings of the 45th ABTCP International Pulp and Paper Congress and VII IberoAmerican Congress on Pulp and Paper Research, Sao Paulo, Brazil, 9-11 October 2012; pp. 1-10.

70. Lourenço, A.; Marques, A.V.; Gominho, J. The identification of new triterpenoids in Eucalyptus globulus wood. Molecules 2021, 26, 3495. [CrossRef] [PubMed]

71. Mączka, W.; Duda-Madej, A.; Górny, A.; Grabarczyk, M.; Wińska, K. Can eucalyptol replace antibiotics? Molecules 2021, $26,4933$. [CrossRef]

72. Salem, N.; Kefi, S.; Tabben, O.; Ayed, A.; Jallouli, S.; Feres, N.; Hammami, M.; Khammassi, S.; Hrigua, I.; Nefisi, S.; et al. Variation in chemical composition of Eucalyptus globulus essential oil under phenological stages and evidence synergism with antimicrobial standards. Ind. Crop. Prod. 2018, 124, 115-125. [CrossRef]

73. Boulekbache-makhlouf, L.; Slimani, S.; Madani, K. Total phenolic content, antioxidant and antibacterial activities of fruits of Eucalyptus globulus cultivated in Algeria. Ind. Crops Prod. 2013, 41, 85-89. [CrossRef]

74. Bachir, R.G.; Benali, M. Antibacterial activity of the essential oils from the leaves of Eucalyptus globulus against Escherichia coli and Staphylococcus aureus. Asian Pac. J. Trop. Biomed. 2012, 2, 739-742. [CrossRef]

75. Esmaeili, D.; Mobarez, A.M.; Tohidpour, A. Anti-Hlicobacter pylori Activities of shoya powder and essential oils of Thymus vulgaris and Eucalyptus globulus. Open Microbiol. J. 2012, 6, 65-69. [CrossRef]

76. Djelloul, R.; Mokrani, K.; Hacini, N. Study of the antibacterial activity of the extract from the essential oil of Eucalyptus globulus and Rosmarinus officinalis on three bacterial strains. Int. J. Appl. Environ. Sci. 2017, 12, 47-56.

77. Limam, H.; Ben Jemaa, M.; Tammar, S.; Ksibi, N.; Khammassi, S.; Jallouli, S.; Del Re, G.; Msaada, K. Variation in chemical profile of leaves essential oils from thirteen Tunisian Eucalyptus species and evaluation of their antioxidant and antibacterial properties. Ind. Crops Prod. 2020, 158, 112964. [CrossRef]

78. Merghni, A.; Noumi, E.; Hadded, O.; Dridi, N.; Panwar, H.; Ceylan, O.; Mastouri, M.; Snoussi, M. Assessment of the antibiofilm and antiquorum sensing activities of Eucalyptus globulus essential oil and its main component 1,8-cineole against methicillinresistant Staphylococcus aureus strains. Microb. Pathog. 2018, 118, 74-80. [CrossRef]

79. Luo, J.; Qi, S.; Peng, L.; Xie, X. Phytoremediation potential of cadmium-contaminated soil by Eucalyptus globulus under different coppice systems. Bull. Environ. Contam. Toxicol. 2015, 94, 321-325. [CrossRef]

80. Luo, J.; Qi, S.; Peng, L.; Wang, J. Phytoremediation efficiency of CD by Eucalyptus globulus transplanted from polluted and unpolluted sites. Int. J. Phytoremediat. 2016, 18, 308-314. [CrossRef] [PubMed]

81. Luo, J.; Qi, S.; Peng, L.; Xie, X. Enhanced phytoremediation capacity of a mixed-species plantation of Eucalyptus globulus and Chickpeas. J. Geochem. Explor. 2017, 182, 201-205. [CrossRef]

82. El-Khatib, A.A.; Youssef, N.A.; Barakat, N.A.; Samir, N.A. Responses of Eucalyptus globulus and Ficus nitida to different potential of heavy metal air pollution. Int. J. Phytoremediat. 2020, 22, 986-999. [CrossRef]

83. Puig, C.G.; Revilla, P.; Barreal, M.E.; Reigosa, M.J.; Pedrol, N. On the suitability of Eucalyptus globulus green manure for field weed control. Crop Prot. 2019, 121, 57-65. [CrossRef]

84. Puig, C.G.; Álvarez-Iglesias, L.; Reigosa, M.J.; Pedrol, N. Eucalyptus globulus leaves incorporated as green manure for weed control in maize. Weed Sci. 2013, 61, 154-161. [CrossRef]

85. Nega, F.; Gudeta, T.B. Allelopathic effect of Eucalyptus globulus Labill. on seed germination and seedling growth of highland teff (Eragrostis tef (Zuccagni) Trotter)) and barely (Hordeum vulgare L.). J. Exp. Agric. Int. 2019, 30, 1-12. [CrossRef] 
86. Pinto, M.; Soares, C.; Martins, M.; Sousa, B.; Valente, I.; Pereira, R.; Fidalgo, F. Herbicidal effects and cellular targets of aqueous extracts from young Eucalyptus globulus Labill. Leaves. Plants 2021, 10, 1159. [CrossRef] [PubMed]

87. Almeida, E.F.A.; Santos, L.O.; Castricini, A.; da Silva Reis, J.B.R. Eucalyptus globulus essential oil on the postharvest quality of "Carola" roses. Ornam. Hortic. 2020, 26, 159-165. [CrossRef]

88. Rani, N.; Harikrishnan, T.J.; Ponnudurai, G. In vitro insecticidal activity of essential oil of Eucalyptus globulus against Musca domestica. Indian Vet. J. 2016, 93, 25-27.

89. Abdelkader, H.; Abdelkader, B.; Yahia, B. Toxicity and repellency of Eucalyptus globulus L. essential oil against Aphis fabae Scopoli, 1763 (Homoptera: Aphididae). J. Entomol. Res. 2020, 44, 147-152. [CrossRef] 